\title{
INFLAMMATORY RESPONSE TO ACUTE EXPOSURE TO WELDING FUMES DURING THE WORKING DAY
}

\section{MERJA JÄRVELÄ ${ }^{1}$, PAULA KAUPPI MD ${ }^{2,3}$, TIMO TUOMI ${ }^{1}$, RITVA LUUKKONEN ${ }^{4}$, HARRI LINDHOLM ${ }^{5}$, RIINA NIEMINEN ${ }^{6}$, EEVA MOILANEN ${ }^{6}$, and TIMO HANNU ${ }^{2,7}$}

${ }^{1}$ Finnish Institute of Occupational Health, Helsinki, Finland

Aerosols, Dusts and Metals

${ }^{2}$ Finnish Institute of Occupational Health, Helsinki, Finland

Occupational Medicine

${ }^{3}$ Skin and Allergy Hospital, Helsinki, Finland

${ }^{4}$ Finnish Institute of Occupational Health, Helsinki, Finland

Statistical Services

${ }^{5}$ Finnish Institute of Occupational Health, Helsinki, Finland

Physical Work Capacity

${ }^{6}$ Medical School, University of Tampere and Research Unit, Tampere University Hospital, Tampere, Finland

The Immunopharmacology Research Group

${ }^{7}$ University of Helsinki, Helsinki, Finland

The Hjelt Institute

\begin{abstract}
Objectives: To investigate cardiorespiratory and inflammatory responses in male workers following exposure to welding fumes and airborne particles in actual workplace conditions. Materials and Methods: We measured blood leukocytes and their differential counts, platelet count, hemoglobin, sensitive C-reactive protein, fibrinogen, E-selectin, IL-(interleukin)1 $\beta$, IL-6, IL-8, tumor necrosis factor alpha (TNF- $\alpha$ ) and endothelin-1 in blood samples of twenty workers before and after their working day. We also studied peak expiratory flow (PEF), forced expiratory volume in one second $\left(\mathrm{FEV}_{1}\right)$, and exhaled nitric oxide $(\mathrm{NO})$. We assessed heart rate variability $(\mathrm{HRV})$ by obtaining 24-hour ambulatory electrocardiograms. Results: The total blood leukocytes and neutrophils increased after the work shift, whereas IL-1 $\beta$ and E-selectin decreased significantly. There were no statistically significant changes in exhaled NO, FEV , PEF or HRV. Conclusion: Occupational exposure to welding fumes and particles caused a slight, acute inflammatory effect estimated based on the increased values of leukocytes and neutrophils in blood and a decrease in the interleukin $1 \beta$ and E-selectin values, but no changes in the pulmonary function (exhaled $\mathrm{NO}, \mathrm{FEV}_{1}, \mathrm{PEF}$ ) or $\mathrm{HRV}$ during the working day were observed.
\end{abstract}

Key words:

Cytokines, E-selectin, Exhaled Nitric Oxide (NO), Heart Rate Variability (HRV), Interleukin-1ß, Welding

Received: April 27, 2012. Accepted: November 11, 2012.

This study was supported by the grant from The Finnish Work Environment Fund (grant number: 106106).

Corresponding author: P. Kauppi, Skin and Allergy Hospital, Meilahdentie 2, PO Box 160, FI-00029 HUS, Helsinki, Finland (e-mail: paula.kauppi@hus.fi). 


\section{INTRODUCTION}

Welding is the most widely used technology for joining metals and alloys. The most common welding processes are manual metal arc welding, gas metal arc welding, flux cored arc welding, gas tungsten arc welding, plasma arc welding, and submerged arc welding. Welding processes produce fumes consisting of gaseous and aerosol by-products composed of metals, metal oxides and volatilized chemical species from the base metals, welding electrode, or flux material [1]. Welding generates individual ultrafine particles (particles smaller than $100 \mathrm{~nm}$ ) that rapidly form larger chain-like aggregates in the fine particle size range. Mild steel welding generates fumes which are composed of $80 \%$ or more iron, some manganese, but no chromium or nickel. Fumes from stainless steel welding contain $20 \%$ of chromium and $10 \%$ of nickel [2]. Fume formation depends on the welding process, electrode composition, welding alloy and arc voltage used [1]. The typical welder's breathing zone fume concentration is between 1 and $5 \mathrm{mg} / \mathrm{m}^{3}[3,4]$. Despite some improvement in the working conditions and welders' use of respiratory protective equipment, such as motorized respirators, workers are still exposed to fumes produced by co-workers, when they themselves perform tasks other than welding.

The pulmonary health effects related to the exposure to welding fumes including chronic bronchitis, pneumonia, metal fume fever, and lung function changes are generally well-known [3,5]. However, a growing concern for cardiovascular health effects has emerged, as several studies have reported an increased mortality risk of ischemic heart disease among welders [2,6-9]. Similar adverse cardiorespiratory effects have been associated with fine particulate air pollution [10-12]. Subsequently, it has been suggested that although welding fumes are of primary interest as workplace exposures, they might also serve as a model representing ambient air particulate pollution [13].

The underlying mechanisms responsible for these cardiorespiratory effects are largely unknown. One of the investigated mechanisms has been the effect of fine particles on autonomic nervous activity. For instance, the association between the mean heart rate variability (HRV) and exposure to welding fumes have been studied $[13,14]$. Another line of research has focused on investigating the possible association between particulate air matter and acute systemic inflammatory responses. Such investigations have also been performed in relation to welding $[13,15,16]$. More recently, acute effects of welding fume exposure on vascular function have also been studied $[14,16]$.

The above-mentioned studies on the mechanisms responsible for cardiorespiratory effects have all been carried out in laboratory environments. Therefore, the results may not be applicable in actual workplace conditions. The present study of 20 subjects investigated the possible effects on the hematological, systemic inflammatory, respiratory and cardiac parameters of exposure to welding fumes and airborne particles in metal workers in welding halls.

\section{MATERIALS AND METHODS}

\section{Study design and study subjects}

This study comprised twenty metal workers who worked in two large plants operating in the metal construction industry. They were exposed to mild steel welding fumes and to dusts and fumes generated from grinding mild steel plates or pieces in large-scale industry halls. Metal inert gas (MIG), metal active gas (MAG), and flux cored arc welding (FCAW) were the main types of welding processes carried out at the plants. Five of the subjects used modern fresh air face shields during the exposure measurements. Each study subject filled in a questionnaire concerning work and exposure history, smoking habits, as well as lung and cardiovascular disease history. The study started on a Monday, so that each subject had at least a two-day break from welding before being tested. Venous blood samples were taken before and at the end of the work shift ( 8 hours after baseline sampling). Baseline peak expiratory flow 
(PEF) and measurements of forced expiratory volume in one second $\left(\mathrm{FEV}_{1}\right)$ and exhaled nitric oxide (NO) were taken before work shift and approximately $24 \mathrm{~h}$ after baseline measurements. Ambulatory 24-hour electrocardiograms (ECG) were commenced before the work shift. Particle exposure was assessed by personal sampling from the breathing zone of each subject. Inclusion in the study required the subjects to be free of long-term asthma medication and antihypertensive medication (beta-antagonist). Each study subject gave a written informed consent, and the study protocol was approved by the Ethics Committee of Helsinki and Uusimaa Hospital District.

\section{Exposure measurements}

Particle measurements were taken during the work shift. Inhalable dust samples were collected from the workers' breathing zones using an IOM sampler with a cellulose acetate filter (AAWP, diameter $25 \mathrm{~mm}$; Millipore, Bedford, Massachusetts, USA). The sampling volumetric flow was adjusted to $2.0 \mathrm{l} / \mathrm{min}$. The sampling time varied from one to three hours representing the average total exposure to that particular task. Additional mini sampler measurements were carried out in case of two workers. The sampling was performed inside the workers' fresh air face shields [17] with the volumetric air flow of $0.75 \mathrm{l} / \mathrm{min}$, and the sampling time varying from one to three hours. Dust samples were analyzed gravimetrically (SFS3860 1988) [18]. In the exposure assessment, the use of a fresh air face shield was taken into account by comparing the breathing zone sampling results to the mini sampler results.

\section{Blood sample measurements}

The concentrations of interleukin (IL)-1 $\beta$, IL-6, IL-8, tumor necrosis factor alpha (TNF- $\alpha$ ), endothelin-1, and E-selectin in plasma samples were determined by enzyme immunoassay (EIA), using commercial reagents (IL- $1 \beta$ and TNF- $\alpha$ : Quantikine HS ELISA, R\&D Systems Europe Ltd, Abindgon, UK; IL-6: PeliPair ELISA, Sanquin, Amsterdam, the Netherlands; IL-8: Opt EIA, BD Biosciences, Erembodegem, Belgium; endothelin-1: QuantiGlo ELISA, R\&D Systems Europe Ltd, Abindgon, UK; E-Selectin: ELISA, HyCult Biotechnology, Uden, the Netherlands).

The platelet count, the leukocytes and their differential count, hemoglobin, hematocrit, sensitive C-reactive protein (CRP), lipids, glucose and the levels of fibrinogen were analyzed using the established methods in United Medix Laboratories Ltd, Espoo, Finland, which operates in accordance with the requirements of the EN ISO 15189 and SFS-EN ISO/IEC 17025 standards.

\section{Respiratory measurements}

A portable, pocketsize spirometer (One Flow, STI MEDICAL, Saint-Romans, France) was used to record lung function measurements $\left(\mathrm{FEV}_{1}, \mathrm{PEF}\right)$. The exhaled NO analyses were performed using the collecting method. The samples were collected during exhalation against standardized resistance to an inert plastic bag. The samples were analyzed using an off-line technique in the laboratory of the Finnish Institute of Occupational Health (NIOX, Aerocrine, Sweden). Both the spirometry and the NO measurements were performed according to the ATS/ERS guidelines [19,20]. For the spirometry, Finnish reference values were used [21].

\section{Heart rate variability measurements}

ECG was registered by a three-channel recorder (DL 700, Braemar, Burnsville, USA), and HRV was analyzed by special software (BMS C3000, Biomedical Systems, USA). The recordings started at the beginning of the work shift (between 9 a.m. and 3 p.m.) and continued for $24 \mathrm{~h}$. The study subjects filled in a diary on their activities during the recording, both at work and at home. The 24-hour ECG recordings were double-checked by two specialists in clinical physiology. In the assessment of heart variability, the domain indices of the time domain parameters were calculated [22]. 


\section{Statistical analysis}

All our response variables were continuous, but not all of them were normally distributed. Therefore, the one-sample Wilcoxon test was applied when the values before and after the work shift were compared. The measured parameters of HRV were compared to the predicted values [23]. Spearman's correlation coefficients were computed to determine the associations between the cardiovascular risk factors (age, lipids, smoking and weight) and the HRV indices. A p-value of $<0.05$ was set to indicate the statistical significance, and all analyses were performed using the Statistical Analysis System, SAS Version 9.1 (SAS Institute Inc., Cary, North Carolina, the USA).

\section{RESULTS}

\section{Study population characteristics}

The mean age of the study subjects was 37.9 years (range: 23-58), and they were all men (Table 1). The average welding history of the study subjects was 13.7 years. Twelve participants were current smokers (60\%), and five had never smoked regularly (25\%). The self-reported physician-diagnosed chronic diseases were as follows: asthma (two subjects), type II diabetes mellitus (one subject), and hypertension (one subject). None of the subjects reported coronary artery disease, cardiac arrhythmia or congenital heart disease.

\section{Particle exposure}

The average 8-hour weighed inhalable dust concentration in the breathing zone was $4 \mathrm{mg} / \mathrm{m}^{3}$ (range: $1.5-35 \mathrm{mg} / \mathrm{m}^{3}$ ) in the welding hall. Inside the workers' fresh air face shields, the dust concentration measured using a mini sampler varied from 0.8 to $2.5 \mathrm{mg} / \mathrm{m}^{3}$. On average, the dust concentrations inside the fresh air face shields were only $8 \%$ of the concentrations measured from the breathing zone using an IOM sampler. Thus, the exposure of the workers who used the fresh air face shields was reduced by $92 \%$.
Table 1. Characteristics of the study subjects $(\mathrm{N}=20)^{*}$

\begin{tabular}{|c|c|}
\hline Parameters & Characteristic \\
\hline Age (years)* & $37.9 \pm 9.7$ \\
\hline BMI* & $27.2 \pm 4.0$ \\
\hline 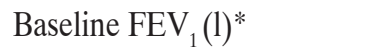 & $3.9 \pm 0.7$ \\
\hline Baseline PEF (1/min)* & $579.0 \pm 66.5$ \\
\hline Cholesterol (mmol/l)* & $5.5 \pm 1.2$ \\
\hline $\mathrm{HDL}(\mathrm{mmol} / \mathrm{l})^{*}$ & $1.4 \pm 0.2$ \\
\hline Triglycerides (mg/l)* & $1.4 \pm 0.4$ \\
\hline Glucose $(\mathrm{mmol} / \mathrm{l})^{*}$ & $6.1 \pm 1.2$ \\
\hline Diagnosed asthma (n) & 2.0 \\
\hline Welding (years)* & $13.7 \pm 10.7$ \\
\hline Exposure $\left(\mathrm{mg} / \mathrm{m}^{3}\right)^{*}$ & $4.0 \pm 2.4$ \\
\hline \multicolumn{2}{|l|}{ Smoking habits (n) } \\
\hline current smokers & 12.0 \\
\hline ex-smokers & 3.0 \\
\hline non-smokers & 5.0 \\
\hline
\end{tabular}

*Values given in means with standard deviation.

$\mathrm{BMI}$ - body mass index; $\mathrm{FEV}_{1}$ - forced expiratory volume in $1 \mathrm{~s} ; \mathrm{PEF}$ peak expiratory flow; HDL - high density lipoprotein.

\section{Changes in the systemic inflammatory marker levels and in the cardiorespiratory function}

Out of the hematological parameters, the hemoglobin level $(\Delta=-7.2 \pm 4.3 \mathrm{~g} / \mathrm{l}, \mathrm{p}<0.01)$ and the number of erythrocytes $\left(\Delta=-0.210^{9} \pm 0.310^{9}\right.$ cells $\left.1^{-1}, \mathrm{p}<0.01\right)$ decreased significantly, whereas the number of leukocytes $\left(\Delta=1.410^{9} \pm 2.210^{9}\right.$ cells $\left.\mathrm{l}^{-1}, \mathrm{p}=0.01\right)$ and neutrophils $\left(\Delta=1.110^{9} \pm 2.310^{9}\right.$ cells $\left.\mathrm{l}^{-1}, \mathrm{p}=0.04\right)$ increased significantly during the workday. Out of the systemic immune parameters, the concentration of IL-1 $\beta$ ( $\Delta=$ $-0.20 \pm 0.30 \mathrm{pg} / \mathrm{ml}, \mathrm{p}=0.01)$ and E-selectin $(\Delta=$ $-2.3 \pm 4.5 \mathrm{ng} / \mathrm{ml}, \mathrm{p}=0.03$ ) decreased significantly (Table 2). The basal level of the exhaled nitric oxide increased (> $30 \mathrm{ppb}$ ) in three study subjects (15\%). There were no statistically significant $\mathrm{FEV}_{1}$ or PEF changes and no asthmatic responses after the work shift, compared to the results of the lung function tests before the work shift 
Table 2. Hematologic and systemic inflammatory parameters and average exhaled nitric oxide (NO), $\mathrm{FEV}_{1}$ and PEF values (SD) before and after the work shift $(\mathrm{N}=20)$

\begin{tabular}{|c|c|c|c|}
\hline \multirow{2}{*}{ Parameters } & \multicolumn{2}{|c|}{ Results } & \multirow{2}{*}{$\mathrm{p}$} \\
\hline & before work shift & after work shift & \\
\hline \multicolumn{4}{|l|}{ Hematologic parameters } \\
\hline hemoglobin (g/l) & $159.10 \pm 10.00$ & $151.90 \pm 10.50$ & $<0.01$ \\
\hline leukocytes $\left(10^{9}\right.$ cells $\left.1^{-1}\right)$ & $8.60 \pm 2.30$ & $10.00 \pm 2.70$ & 0.01 \\
\hline neutrophils $\left(10^{9}\right.$ cells $\left.1^{-1}\right)$ & $5.00 \pm 1.90$ & $6.10 \pm 2.20$ & 0.04 \\
\hline lymphocytes $\left(10^{9}\right.$ cells $\left.\mathrm{l}^{-1}\right)$ & $2.70 \pm 0.80$ & $2.90 \pm 0.90$ & 0.19 \\
\hline eosinophils $\left(10^{9}\right.$ cells $\left.1^{-1}\right)$ & $0.32 \pm 0.21$ & $0.27 \pm 0.16$ & 0.15 \\
\hline erytrocytes $\left(10^{12}\right.$ cells $\left.1^{-1}\right)$ & $5.10 \pm 0.30$ & $4.90 \pm 0.30$ & $<0.01$ \\
\hline monocytes $\left(10^{9}\right.$ cells $\left.^{-1}\right)$ & $0.49 \pm 0.14$ & $0.56 \pm 0.19$ & 0.04 \\
\hline basophils $\left(10^{9}\right.$ cells $\left.\mathrm{l}^{-1}\right)$ & $0.10 \pm 0.04$ & $0.09 \pm 0.04$ & 1.00 \\
\hline platelet count $\left(10^{9}\right.$ cells $\left.1^{-1}\right)$ & $284.00 \pm 75.60$ & $279.10 \pm 76.90$ & 0.08 \\
\hline \multicolumn{4}{|l|}{ Systemic inflammatory parameters } \\
\hline sensitive CRP (mg/ml) & $2.00 \pm 3.50$ & $2.30 \pm 3.90$ & 0.11 \\
\hline P-fibrinogen (g/l) & $3.40 \pm 1.10$ & $3.30 \pm 1.10$ & 0.39 \\
\hline $\mathrm{IL}-1 \beta(\mathrm{pg} / \mathrm{ml})$ & $0.49 \pm 0.30$ & $0.29 \pm 0.14$ & 0.01 \\
\hline IL-6 (pg/ml) & $3.60 \pm 2.30$ & $4.10 \pm 2.40$ & 0.08 \\
\hline IL-8 (pg/ml) & $5.90 \pm 3.60$ & $4.40 \pm 1.50$ & 0.82 \\
\hline $\mathrm{TNF}-\alpha(\mathrm{pg} / \mathrm{ml})$ & $1.30 \pm 0.50$ & $1.10 \pm 0.40$ & 0.11 \\
\hline endothelin-1 (pg/ml) & $1.16 \pm 0.96$ & $1.19 \pm 0.61$ & 0.36 \\
\hline E-selectin (ng/ml) & $60.10 \pm 22.70$ & $57.80 \pm 23.40$ & 0.03 \\
\hline \multicolumn{4}{|l|}{ Pulmonary function values } \\
\hline exhaled NO (ppb) & $20.00 \pm 12.50$ & $19.40 \pm 14.80$ & 0.21 \\
\hline $\mathrm{FEV}_{1}(\mathrm{l})$ & $3.90 \pm 0.70$ & $3.90 \pm 0.70$ & 0.12 \\
\hline $\operatorname{PEF}(1 / \min )$ & $578.00 \pm 66.50$ & $581.00 \pm 63.90$ & 0.88 \\
\hline
\end{tabular}

Abbreviations as in Table 1.

(Table 2). However, all participants whose exhaled NO values were above $30 \mathrm{ppb}$, had the $\mathrm{FEV}_{1}$ values which diminished after the work shift (data not shown).

In the 24-hour heart rate recordings, the main time domainindices of HRV were normal (Table 3). The hourly means of the HRV indices were normal during the working day and showed normal age-related day-night variations. A statistically significant correlation between the HRV indices and the cardiovascular risk factors (age, lipids, smoking and weight) was found between pNN50 (percentage of the number of pairs of adjacent RR intervals differing by more than $50 \mathrm{~ms}$ of all RR intervals) and age $(\mathrm{r}=0.47, \mathrm{p}=0.04)$. 
Table 3. Main findings in 24-hour ECG recordings $(\mathrm{N}=20)$

\begin{tabular}{lcc}
\hline \multicolumn{1}{c}{ Parameters } & M \pm SD & Range \\
\hline Mean heart rate (24 h, beats/min) & $85.0 \pm 10.6$ & $65-105$ \\
rMSSD (ms) & $41.7 \pm 18.5$ & $15-92$ \\
SDNN (ms) & $164.0 \pm 51.7$ & $104-259$ \\
pNN50 $(\%)$ & $10.6 \pm 9.4$ & $0-36$ \\
Ventricular extrasystoles (beats/24 h) & $63.0 \pm 203.0$ & $0-888$ \\
\hline
\end{tabular}

$\mathrm{M}$ - mean; SD - standard deviation; rMSSD = square root of the mean of the sum of squares of the differences between the adjacent RR intervals; SDNN = standard deviation of the RR intervals over $24 \mathrm{~h}$; pNN50 = percentage of the NN50 count of all RR intervals (NN50= the number of pairs of the adjacent RR intervals differing by more than $50 \mathrm{~ms}$ ).

\section{DISCUSSION}

In the present study, cardiorespiratory and inflammatory effects were investigated in twenty male metal workers exposed to welding fumes and dusts and fumes generated from the grinding of mild steel plates or pieces in actual workplace conditions. The hemoglobin and erythrocyte levels decreased significantly during the working day. Although this finding has not been observed in other studies dealing with acute effects of welding fumes [13,15,24], a significant association between the concentration of particulate matter $\left(\mathrm{PM}_{10}\right)$ and blood hemoglobin levels has been reported [25]. As regards a possible mechanism, the investigators suggested that inhalation of a component of $\mathrm{PM}_{10}$ may cause the sequestration of red cells in circulation. A decrease in the red blood cell count and the hemoglobin concentration was also found in the elderly subjects exposed to concentrated ambient particles smaller than $2.5 \mu \mathrm{m}$ [26]. In our study, the decrease in the hemoglobin levels could be caused by differences in the metabolic intensity and fluid shifts during moderate or low level physical work [27].

The number of blood leukocytes and neutrophils increased significantly in our series. This is in line with the results obtained by Kim et al. (2005) [15], who found that welding fume exposure was associated with a significant increase in white blood cell and neutrophil counts, although this finding was only evident in non-smokers. However, this had not been reported in previous studies dealing with acute effects of welding [13,24]. Welding fume exposure has been related to increased levels of CRP, an acute phase protein and early indicator of systemic inflammation, in non-smokers [15]. However, no statistical differences in the CRP levels were found in two other previous researches $[13,24]$. In line with these two studies, we found no statistical differences in the CRP level, either.

Cytokines are small multifunctional polypeptides produced by a variety of cells [28]. Out of these, IL- 6 and IL-8 are synthesized in the liver and produced by inflammatory cells such as macrophages and neutrophilic leukocytes in response to local injury. They are well-studied acute phase inflammatory markers, and are also tested following the welding fume exposure [13,24]. In an English study by Palmer et al. (2006), IL-8 was measured in the sputum of welders and non-welders [24]. Sputum IL-8 was slightly, but not statistically significantly lower among the welders. Scharrer et al. studied blood IL-8 and IL-6, but did not find any significant differences in the cytokine levels between the control and exposure days [13]. We measured both these cytokines and found no statistically significant differences either, although there was a small increase in the level of IL- 6 and a small decrease in the IL-8 level. A similar trend was observed in the aforementioned German study [13]. Although detectable levels of TNF- $\alpha$ have been reported in lavage after welding fume instillation [29] in rats, no statistical differences in the TNF- $\alpha$ levels in sputum or blood following the welding exposure 
have been reported in humans [13,24]. Our study confirms the findings of the previous human studies.

We also studied the role of IL-1 $\beta$, which is produced in acute phase reactions by blood monocytes and macrophages. It induces fever and causes leukocytosis through the release of neutrophils and stimulates the production of other cytokines, such as IL-6 [28]. Unexpectedly, the IL-1 $\beta$ levels, which had not previously been studied in welders, decreased significantly in our study population. These have been shown to increase in rats after intratracheal instillation of the welding fumes [29] and in human nasal lavage fluid after exposure to Aspergillus fumigatus [30]. The elevation of the circulating IL-1 $\beta$ levels is also associated with particulate air pollution [31,32]. The data of the concurrent study do not allow for the unfolding of the mechanisms underlying the observed response of IL-1 $\beta$. However, the timing of the blood samples is critical in order to show a marked response, because it is known that markers of acute phase reaction may increase during the inflammatory response or decrease as a sign of more profound consumption.

There are no previous studies reporting the E-selectin levels following the exposure to welding fumes. E-selectin is formed in the endothelial cells and is needed in the leukocyte adhesion cascade, where leukocytes roll along blood vessel walls before entering the tissue [33]. It has been associated with acute myocardial infarction [34] or coronary artery disease [35]. In our study, the E-selectin level decreased significantly, while the number of leukocytes increased during the work shift.

Endothelin-1 is a vasoconstrictor peptide involved in the homeostatic control of vascular smooth muscle tone [36]. The circulating endothelin-1 levels are elevated in many cardiovascular diseases, such as atherosclerosis, congestive heart failure, and hypertension [37]. Endothelin-1 is detected in both animal models and humans after exposure to air pollutants [38,39]. We found no significant changes in the endothelin-1 levels, which is not in accordance with a previous study reporting a decrease in endothelin-1 following welding fume exposure in healthy volunteers [13]. In that study, the authors indicate that their observed paradoxical response could be related to the fact that differential effects have been described connected with the constituents of welding fumes, such as particles and ozone.

Out of coagulation parameters, we studied fibrinogen, a soluble plasmaprotein, which is produced in the liver and converted into fibrin in clot formation. In this process, platelets are also used. We found no changes as regards the fibrinogen levels, which is in line with the results of Scharrer et al. [13]. However, Kim et al. [15] reported a significant decrease in the fibrinogen levels after exposure to welding fumes, although only among non-smokers. In our study, no significant changes in the HRV parameters in relation to occupational exposure were evident. Previous investigations reported contradictory results concerning welding and HRV. Scharrer et al. [13] studied the time- and frequency-domain parameters of HRV, but found no changes in them five hours after the welding exposure compared to the control. Cavallari et al. [40], similarly to us, used the ambulatory recording method and observed declines in the night rMSSD associated with the exposure of the welders to $\mathrm{PM}_{2.5}$. Another study showed an association between the exposure to environmental $\mathrm{PM}_{2.5}$ and welding fumes, and a decrease in the five-minute SDNN [41], a finding also made by Fang et al. [14]. According to a recent review, the HRV indices as well as the conditions for ECG ascertainment have varied between different studies, which may affect their comparison [16]. It has been suggested that individual risk factors, such as obesity, may modify the effect of the exposure to particulate matter on HRV [42]. In line with this, we found a statistically significant correlation between the cardiovascular risk factors (age, lipids, smoking and weight) and HRV (pNN50). Our results support the view that in addition to the control of environmental exposures, the management of traditional cardiovascular risk factors is important in the occupational health of welders. The correlation between the inflammatory markers and the 
frequency-domain parameters or other more sophisticated parameters of HRV was not investigated.

We found no changes in the pulmonary function or in the exhaled NO levels measured at the beginning of the working day and $24 \mathrm{~h}$ after it. The exhaled NO levels in welders had not been previously reported. Welding has earlier been associated with reduced pulmonary function, especially in poorly ventilated working conditions [43,44]. The reduction of the lung function parameters measured before and after the work shift is reported to be approximately four times greater among welders than among the non-exposed controls [43]. In another study, significantly lower PEF values were observed in the welders compared to the non-welders at 15 min since the beginning of the working week [45]. The timing of the lung function measurements is important: changes in the welders' lung function may be transient, occurring at the time of the exposure in the workplace and returning to normal during the non-exposure periods [46]. We measured PEF and $\mathrm{FEV}_{1}$ on Monday after a non-exposure weekend and on Tuesday morning approximately 16 hours after the work shift. No across-shift or immediately-after-shift measurements were carried out.

In our study, the relatively small sample size did not allow for a subgroup analysis of the smoking subjects vs. the nonsmoking subjects or the use of fresh air face shields. Furthermore, the timing of the blood samples is critical in order to show a marked response in the hematological or inflammatory parameters, but we had no technical facilities for taking more samples within a more dense time protocol. The timing of the outcome measurements may explain some of the discrepancies observed in the studies performed [35]. In addition, the study individuals represented their own controls in the present study, which should be considered when assessing the results. The strength of our study is that it was conducted in actual working conditions in welding halls. Therefore, its findings might be more applicable in risk assessment procedures at workplaces than the findings from the studies performed in laboratory environments.
In conclusion, occupational exposure to welding fumes and dusts and fumes generated from grinding mild steel plates or pieces in actual workplace conditions caused a slight, acute inflammation in metal workers observed as an increase in the total blood leukocytes and neutrophils, as well as a decrease of IL-1 $\beta$ and E-selectin after the work shift. No changes were found in the pulmonary function $\left(\mathrm{FEV}_{1}, \mathrm{PEF}\right.$, exhaled $\left.\mathrm{NO}\right)$ or in HRV.

\section{ACKNOWLEDGEMENTS}

The authors wish to thank Tiina Anttinen-Klemetti, Kaarina Eklöf, Bernt Engström, and Heli Sistonen for their excellent work in workplace particle measurements, and Alice Lehtinen for the language revision of this article.

\section{REFERENCES}

1. Zimmer AT, Biswas P. Characterization of the aerosols resulting from arc welding processes. J Aerosol Sci 2001;32:993-1008.

2. Antonini JM. Health effects of welding. Crit Rev Toxicol 2003;33(1):61-103.

3. Antonini JM, Taylor MD, Zimmer AT, Roberts JR. Pulmonary responses to welding fumes: Role of metal constituents. J Toxicol Environ Health A 2004;67(3):233-49. DOI: $10.1080 / 15287390490266909$.

4. Ulfvarson U. Survey of air contaminants from welding. Scand J Work Environ Health 1981;7 Suppl 2:1-28.

5. Hannu T, Piipari R, Tuppurainen M, Nordman H, Tuomi T. Occupational asthma caused by stainless steel welding fumes: A clinical study. Eur Respir J 2007;29(1):85-90. DOI 10.1183/09031936.00058106.

6. Newhouse ML, Oakes D, Woolley AJ. Mortality of welders and other craftsmen at a shipyard in NE England. Br J Ind Med 1985;42(6):406-10.

7. Moulin JJ, Wild P, Haguenoer JM, Faucon D, de Gaudemaris R, Mur JM, et al. A mortality study among mild steel and stainless steel welders. Br J Ind Med 1993;50(3):234-43. 
8. Sjögren B, Fossum T, Lindh T, Weiner J. Welding and ischemic heart disease. Int J Occup Environ Health 2002;8(4): 309-11.

9. Steenland K. Ten-year update on mortality among mild-steel welders. Scand J Work Environ Health 2002;28(3):163-7. DOI: 10.5271/sjweh.660.

10. Dockery DW, Pope CA 3rd, Xu X, Spengler JD, Ware JH, Fay ME, et al. An association between air pollution and mortality in six U.S. cities. N Engl J Med 1993;329(24):1753-9. DOI 10.1056/NEJM199312093292401.

11. Pope CA, Burnett RT, Thun MJ, Calle EE, Krewski D, Ito $\mathrm{K}$, et al. Lung cancer, cardiopulmonary mortality, and long-term exposure to fine particulate air pollution. JAMA 2002;287(9):1132-41. DOI: 10.1001/jama.287.9.1132.

12. Pope CA, Burnett RT, Thurston GD, Thun MJ, Calle EE, Krewski D, et al. Cardiovascular mortality and long-term exposure to particulate air pollution. Circulation 2004;109(1):71-7. DOI: 10.1161/01.CIR.0000108927.80044.7F.

13. Scharrer E, Hessel H, Kronseder A, Guth W, Rolinski B, Jorres RA, et al. Heart rate variability, hemostatic and acute inflammatory blood parameters in healthy adults after shortterm exposure to welding fume. Int Arch Occup Environ Health 2007;80(4):265-72. DOI: 10.1007/s00420-006-0127-2.

14. Fang SC, Cavallari JM, Eisen EA, Chen JC, Mittleman MA, Christiani DC. Vascular function, inflammation, and variations in cardiac autonomic responses to particulate matter among welders. Am J Epidemiol 2009;169(7):848-56. DOI: 10.1093/aje/kwn405.

15. Kim JY, Chen JC, Boyce PD, Christiani DC. Exposure to welding fumes is associated with acute systemic inflammatory responses. Occup Environ Med 2005;62(3):157-63. DOI: 10.1136/oem.2004.014795.

16. Fang SC, Cassidy A, Christiani DC. A systematic review of occupational exposure to particulate matter and cardiovascular disease. Int J Environ Res Public Health 2010;7(4):1773-806. DOI: 10.3390/ijerph7041773.

17. Liden G, Surakka J. A headset-mounted mini sampler for measuring exposure to welding aerosol in the breathing zone.
Ann Occup Hyg 2009;53(2):99-116. DOI: 10.1093/annhyg/ mep001.

18. SFS3860:1988. Measurement of dust concentration in workplace air with filter method. Helsinki: Finnish Standards Association SFS; 1988.

19. Miller MR, Hankinson J, Brusasco V, Burgos F, Casaburi R, Coates A, et al. ATS/ERS Task Force. Standardisation of spirometry. Eur Respir J 2005;26(2):319-38. DOI: 10.1183/0 9031936.05.00034805.

20. American Thoracic Society Documents. ATS/ERS recommendations for standardized procedures for the online and offline measurement of exhaled lower respiratory nitric oxide and nasal nitric oxide, 2005. Am J Respir Crit Care Med 2005;171(8):912-30. DOI: 10.1164/rccm.200406-710ST.

21. Viljanen AA, Halttunen PK, Kreus KE, Viljanen BC. Spirometric studies in non-smoking, healthy adults. Scand J Clin Lab Invest Suppl. 1982;159:5-20.

22. Malik M, Camm J. Dynamic electrocardiography. New York: Blackwell Futura; 2004.

23. Bonnemeier H, Richardy G, Potraz G, Wiegand U, Brandes A, Kluge N, et al. Circadian profile of cardiac autonomic nervous modulation in healthy subjects: differing effects of aging and gender on heart rate variability. J Cardiovasc Electrophysiol 2003;14(8):791-9.

24. Palmer KT, McNeill Love RM, McNeill Love R, Poole JR, Coggon $\mathrm{D}$, Frew AJ, et al. Inflammatory responses to the occupational inhalation of metal fume. Eur Respir J 2006;27(2): 366-73. DOI: 10.1183/09031936.06.00053205.

25. Seaton A, Soutar A, Crawford V, Elton R, McNerlan S, Cherrie J, et al. Particulate air pollution and the blood. Tho$\operatorname{rax} 1999 ; 54(11): 1027-32$.

26. Gong H, Linn WS, Terrell SL, Anderson KR, Clark KW, Sioutas $\mathrm{C}$, et al. Exposures of elderly volunteers with and without chronic obstructive pulmonary disease (copd) to concentrated ambient fine particulate pollution. Inhal Toxicol 2004;16 (11-12):731-44. DOI: 10.1080/08958370490499906.

27. Harrison MH. Effects on thermal stress and exercise on blood volume in humans. Physiol Rev 1985;65(1):149-209. 
28. Barnes PJ, Chung KF, Page CP. Inflammatory mediators of asthma: An update. Pharmacol Rev 1998;50(4):515-96.

29. Antonini JM, Krishna Murthy GG, Brain JD. Responses to welding fumes: Lung injury, inflammation, and the release of tumor necrosis factor-alpha and interleukin-1 beta. Exp Lung Res 1997;23(3):205-27.

30. Stark H, Roponen M, Purokivi M, Randell J, Tukiainen H, Hirvonen MR. Aspergillus fumigatus challenge increases cytokine levels in nasal lavage fluid. Inhal Toxicol 2006;18(13):1033-9. DOI 10.1080/08958370600904579.

31. Tornqvist H, Mills NL, Gonzalez M, Miller MR, Robinson SD, Megson IL, et al. Persistent endothelial dysfunction in humans after diesel exhaust inhalation. Am J Respir Crit Care Med 2007;176(4):395-400. DOI: 10.1164/rccm.200606-872OC.

32. Van Eeden SF, Tan WC, Suwa T, Mukae H, Terashima T, Fujii $\mathrm{T}$, et al. Cytokines involved in the systemic inflammatory response induced by exposure to particulate matter air pollutants (PM10). Am J Respir Crit Care Med 2001;164(5):826-30.

33. Dong ZM, Chapman SM, Brown AA, Frenette PS, Hynes RO, Wagner DD. The combined role of $P$ - and E-selectins in atherosclerosis. J Clin Invest 1998;102(1): 145-52. DOI: 10.1172/JCI3001.

34. Suefuji H, Ogawa H, Yasue H, Sakamoto T, Miyao Y, Kaikita $\mathrm{K}$, et al. Increased plasma level of soluble E-selectin in acute myocardial infarction. Am Heart J 2000;140(2):243-8. DOI: $10.1067 / \mathrm{mhj} .2000 .107544$.

35. Fang L, Wei H, Mak KH, Xiong Z, Song J, Wang D, et al. Markers of low-grade inflammation and soluble cell adhesion molecules in Chinese patients with coronary artery disease. Can J Cardiol 2004;20(14):1433-8.

36. Haynes WG, Ferro CE, Webb DJ. Physiologic role of endothelin in maintenance of vascular tone in humans. J Cardiovasc Pharmacol 1995;26 Suppl 3:183-5.

37. Luscher TF, Barton M. Endothelins and endothelin receptor antagonists: Therapeutic considerations for a novel class of cardiovascular drugs. Circulation 2000;102(19):2434-40. DOI: 10.1161/01.CIR.102.19.2434.
38. Calderon-Garciduenas L, Vincent R, Mora-Tiscareno A, Franco-Lira M, Henriquez-Roldan C, BarraganMejia G, et al. Elevated plasma endothelin-1 and pulmonary arterial pressure in children exposed to air pollution. Environ Health Perspect 2007;115(8):1248-53. DOI: 10.1289/ ehp. 9641.

39. Thomson E, Goegan P, Kumarathasan P, Vincent R. Air pollutants increase gene expression of the vasoconstrictor endothelin-1 in the lungs. Biochim Biophys Acta 2004;1689(1):75-82. DOI: 10.1016/j.bbr.2011.03.031.

40. Cavallari JM, Eisen EA, Fang SC, Schwartz J, Hauser R, Herrick RF, et al. PM2.5 metal exposures and nocturnal heart rate variability: A panel study of boilermaker construction workers. Environ Health 2008;7:36. DOI: 10.1186/1476069X-7-36.

41. Magari SR, Hauser R, Schwartz J, Williams PL, Smith TJ, Christiani DC. Association of heart rate variability with occupational and environmental exposure to particulate air pollution. Circulation 2001;104(9):986-91. DOI: 10.1161/ hc3401.095038.

42. Chen J-C, Cavallari JM, Stone PH, Christiani DC. Obesity is a modifier of autonomic cardiac responses to fine metal particulates. Environ Health Perspect 2007;115(7):1002-6. DOI: $10.1289 /$ ehp. 9609.

43. Akbar-Khanzadeh F. Short-term respiratory function changes in relation to workshift welding fume exposures. Int Arch Occup Environ Health 1993;64(6):393-7.

44. Mur JM, Teculescu D, Pham QT, Gaertner M, Massin N, Meyer-Bisch C, et al. Lung function and clinical findings in a cross-sectional study of arc welders. An epidemiological study. Int Arch Occup Environ Health 1985;57(1):1-17.

45. Donoghue AM, Glass WI, Herbison GP. Transient changes in thepulmonaryfunction of welders:Acrosssectionalstudyofmondaypeakexpiratoryflow. OccupEnvironMed1994;51(8):553-6. 46. Sferlazza SJ, Beckett WS. The respiratory health of welders. Am Rev Respir Dis 1991;143(5 Pt 1):1134-48.

This work is available in Open Access model and licensed under a Creative Commons Attribution-NonCommercial 3.0 Poland License - http://creativecommons.org/ licenses/by-nc/3.0/pl/deed.en. 